\title{
RTD Biodiesel (B20) Transit Bus Evaluation: Interim Review Summary
}

K. Proc, R. Barnitt, and R.L. McCormick

Technical Report NREL/TP-540-38364

August 2005 
RTD Biodiesel (B20) Transit Bus Evaluation: Interim Review Summary

K. Proc, R. Barnitt, and R.L. McCormick

Prepared under Task No. FC05.9400
Technical Report NREL/TP-540-38364

August 2005

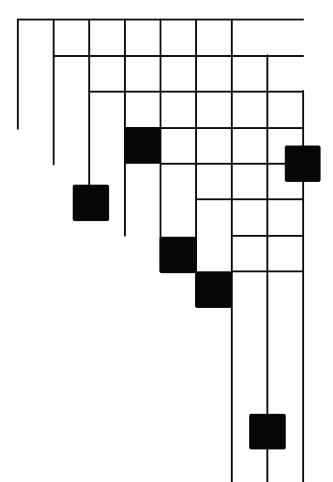




\section{NOTICE}

This report was prepared as an account of work sponsored by an agency of the United States government. Neither the United States government nor any agency thereof, nor any of their employees, makes any warranty, express or implied, or assumes any legal liability or responsibility for the accuracy, completeness, or usefulness of any information, apparatus, product, or process disclosed, or represents that its use would not infringe privately owned rights. Reference herein to any specific commercial product, process, or service by trade name, trademark, manufacturer, or otherwise does not necessarily constitute or imply its endorsement, recommendation, or favoring by the United States government or any agency thereof. The views and opinions of authors expressed herein do not necessarily state or reflect those of the United States government or any agency thereof.

Available electronically at http://www.osti.gov/bridge

Available for a processing fee to U.S. Department of Energy and its contractors, in paper, from:

U.S. Department of Energy

Office of Scientific and Technical Information

P.O. Box 62

Oak Ridge, TN 37831-0062

phone: 865.576 .8401

fax: 865.576 .5728

email: mailto:reports@adonis.osti.gov

Available for sale to the public, in paper, from:

U.S. Department of Commerce

National Technical Information Service

5285 Port Royal Road

Springfield, VA 22161

phone: 800.553.6847

fax: 703.605.6900

email: orders@ntis.fedworld.gov

online ordering: http://www.ntis.gov/ordering.htm 


\section{RTD Biodiesel (B20) Transit Bus Evaluation Interim Review Summary}

The National Renewable Energy Laboratory (NREL) has been working with the Regional Transportation District (RTD) of Denver, Blue Sun Biodiesel, and Power Service Products to evaluate the in-use performance of buses operating on B20 (20\% biodiesel and $80 \%$ conventional diesel fuel). Nine mechanically identical 40 -foot transit buses (five operated on B20, four on conventional diesel) are being compared over the same duty cycle, the "Skip" route in Boulder, Colorado. In addition, laboratory tests compared the buses for fuel economy and emissions. This report summarizes the interim results for the period August 2004 through February 2005.

With fuel, labor, and parts data from RTD, NREL is documenting and analyzing vehicle operation. The objective is to compare B20 and conventional diesel buses in terms of engine performance, component wear, fuel economy, vehicle maintenance, and emissions. The results will help RTD — and other potential biodiesel users - consider future use of biodiesel fuel blends. The results also will help engine manufacturers in exploring the effects of B20 on engine durability.

\section{On-Road Evaluation Results}

Data collection began in late July 2004. The following are results for the 7 months of on-road data analyzed:

- The five B20 buses accumulated approximately 150,000 miles on B20 with the same use as the four diesel comparison buses, approximately 4,500 miles per bus per month (Figure 1). The B20 buses consumed approximately 5,000 gallons of fuel per month.

- There was no significant difference between the average fuel economies of the two groups $-4.59 \mathrm{mpg}$ for the diesel buses, $4.53 \mathrm{mpg}$ for the B20 buses (Figure 2).

- Average miles between road calls were 4,157 miles for the diesel buses, 4,686 miles for the B20 buses (Figure 3).

- Total maintenance costs for the two groups were $\$ 0.51 /$ mile for the diesel buses, $\$ 0.47 / \mathrm{mile}$ for the B20 buses (Figure 4). Engine and fuel system maintenance costs were $\$ 0.04 / \mathrm{mile}$ for the diesel buses, $\$ 0.03 / \mathrm{mile}$ for the B20 buses. These differences in maintenance cost are not believed to be significant. Labor cost is assumed to be $\$ 50 /$ hour for all maintenance cost calculations.

\section{Laboratory Test Results}

- Bus emissions were measured on a chassis dynamometer over the City Suburban Heavy Vehicle Cycle (CSHVC), because the CSHVC is similar to the Skip route duty cycle. In these laboratory tests, buses fueled with B20 demonstrated lower fuel economy and emissions (Figure 5), results that are significant at the $99 \%$ confidence level:

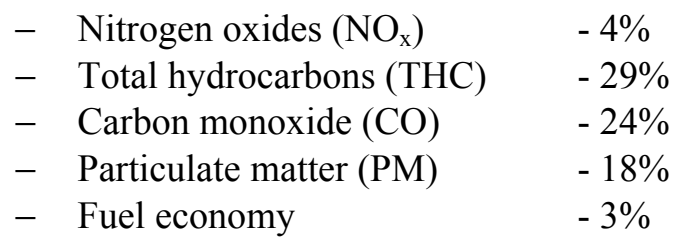

As of this date the buses have completed 12 months of operation on B20. Based on the positive results and high quality data obtained to date, the buses will be evaluated for a $2^{\text {nd }}$ year of operation to provide additional B20 fuel and maintenance history and longer-term engine durability information. NREL will continue to provide data analysis and reporting of project results. 


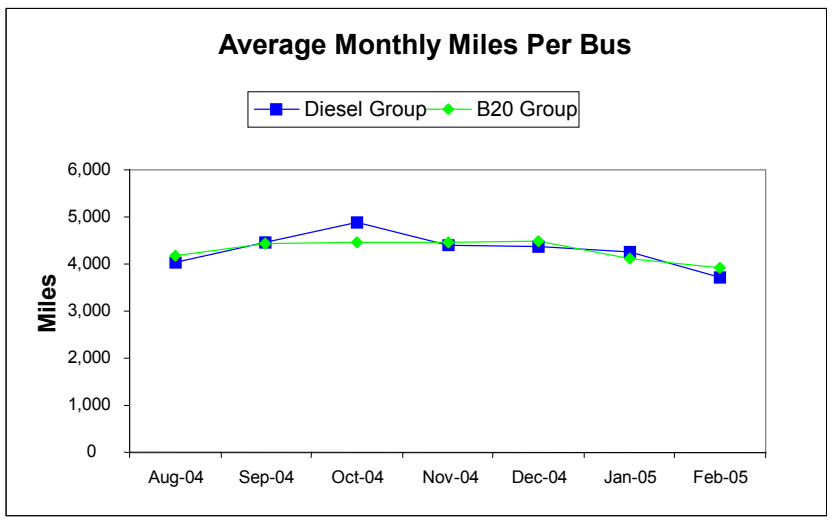

Figure 1

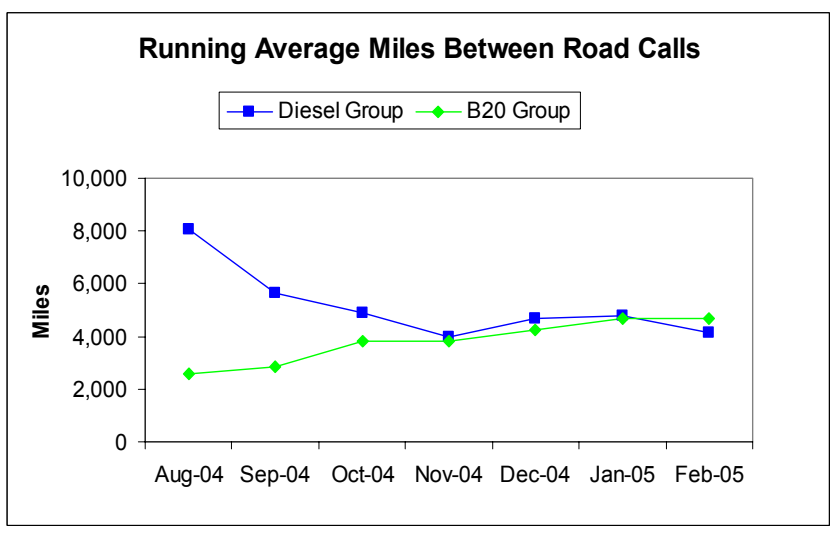

Figure 3

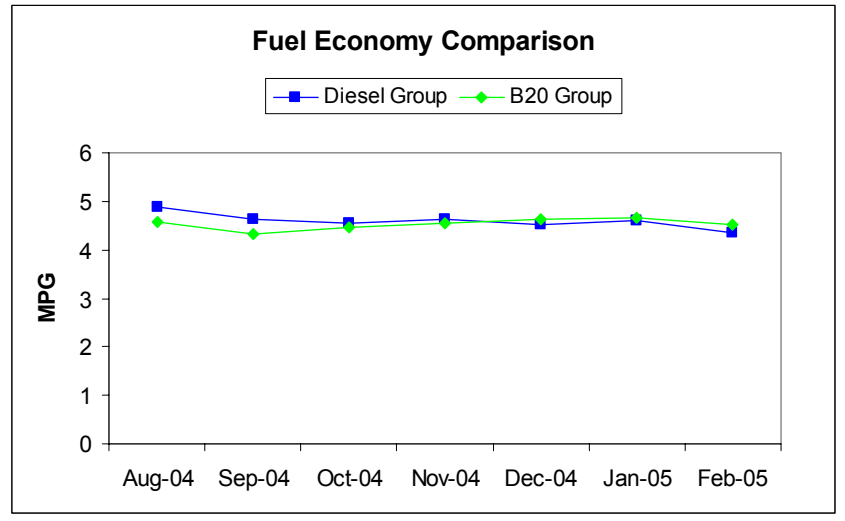

Figure 2

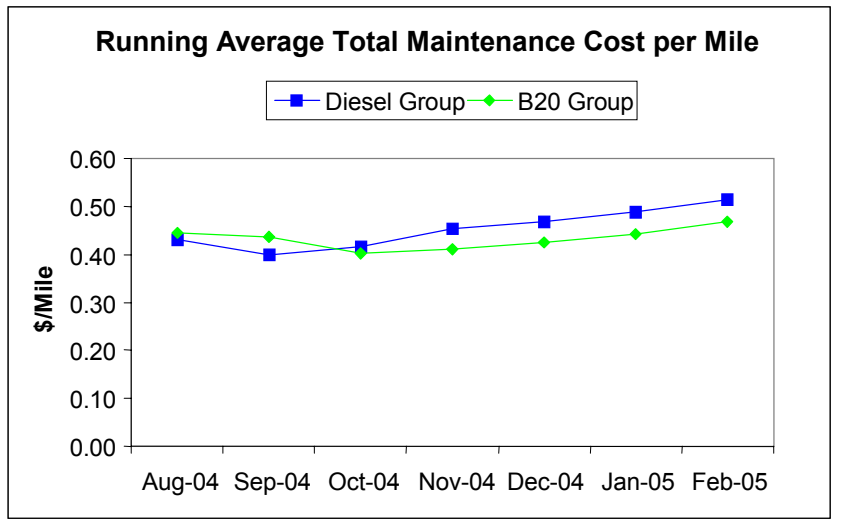

Figure 4

Laboratory Test Results

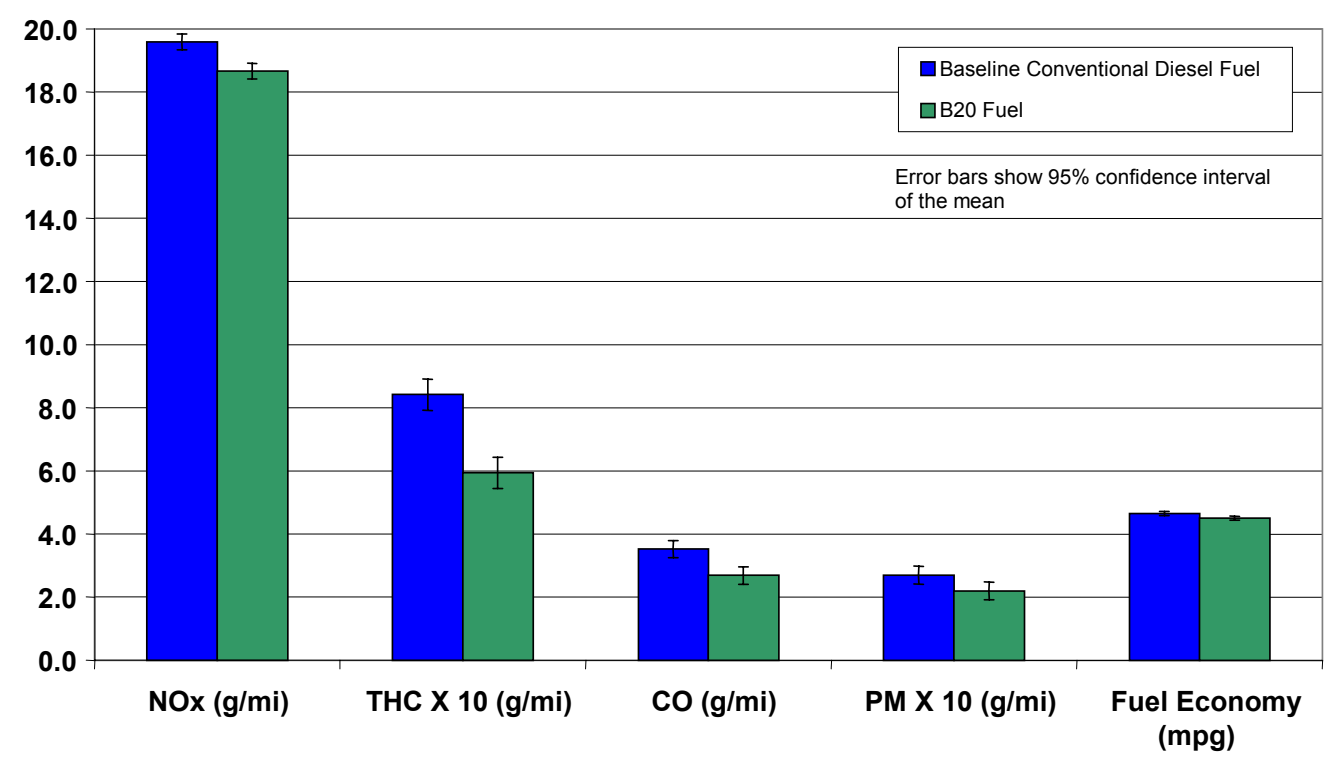

Figure 5 


\section{REPORT DOCUMENTATION PAGE}

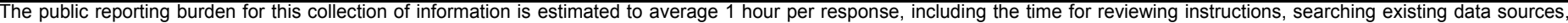

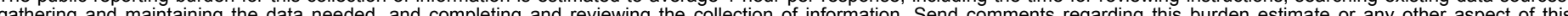
(0704-0188). Respondents

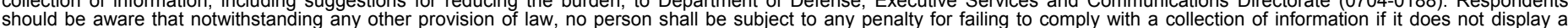

should be aware that notwithstandir

PLEASE DO NOT RETURN YOUR FORM TO THE ABOVE ORGANIZATION.

\begin{tabular}{l|l|l|l} 
1. REPORT DATE $(D D-M M-Y Y Y Y)$ & 2. & REPORT TYPE & 3. DATES COVERED (FrOm - TO)
\end{tabular}

August 2005

Technical Report

4. TITLE AND SUBTITLE

RTD Biodiesel (B20) Transit Bus Evaluation: Interim Review Summary

5a. CONTRACT NUMBER

DE-AC36-99-G010337

5b. GRANT NUMBER

5c. PROGRAM ELEMENT NUMBER

6. AUTHOR(S)

K. Proc, R. Barnitt, and R.L. McCormick

5d. PROJECT NUMBER

NREL/TP-540-38364

5e. TASK NUMBER

FC05.9400

5f. WORK UNIT NUMBER

7. PERFORMING ORGANIZATION NAME(S) AND ADDRESS(ES)

National Renewable Energy Laboratory

1617 Cole Blvd. REPORT NUMBER

Golden, CO 80401-3393

NREL/TP-540-38364

9. SPONSORING/MONITORING AGENCY NAME(S) AND ADDRESS(ES)

10. SPONSOR/MONITOR'S ACRONYM(S) NREL

11. SPONSORING/MONITORING AGENCY REPORT NUMBER

12. DISTRIBUTION AVAILABILITY STATEMENT

National Technical Information Service

U.S. Department of Commerce

5285 Port Royal Road

Springfield, VA 22161

13. SUPPLEMENTARY NOTES

14. ABSTRACT (Maximum 200 Words)

A summary of the data NREL collected from a project to evaluate the in-use performance of buses from the Regional Transportation District of Denver operating on B20.

15. SUBJECT TERMS

B20; biodiesel; biodiesel blends; transit buses; RTD; Regional Transportation District;

\begin{tabular}{|c|c|c|}
\hline 6. SECURIT & CLA & N OF: \\
\hline $\begin{array}{l}\text { a. REPORT } \\
\text { Unclassified }\end{array}$ & $\begin{array}{l}\text { b. ABSTRACT } \\
\text { Unclassified }\end{array}$ & $\begin{array}{l}\text { c. THIS PAGE } \\
\text { Unclassified }\end{array}$ \\
\hline
\end{tabular}

\begin{tabular}{|c|c|}
\hline $\begin{array}{l}\text { 17. LIMITATION } \\
\text { OF ABSTRACT }\end{array}$ & $\begin{array}{l}\text { 18. NUMBER } \\
\text { OF PAGES }\end{array}$ \\
\hline UL & \\
\hline
\end{tabular}

19a. NAME OF RESPONSIBLE PERSON

19b. TELEPHONE NUMBER (Include area code) 